\title{
Vulnerability and adaptation to climate change in the Comoe River Basin (West Africa)
}

\author{
Wonnan Eugène Yéo ${ }^{1 *}$, Bi Tié Albert Goula², Bernd Diekkrüger and Abel Afouda
}

\author{
${ }^{*}$ Correspondence: \\ eugenewyn@gmail.com \\ ${ }^{1}$ GRP CC \& Water Resources, \\ University Abomey Calavi, \\ Cotonou, Benin \\ Full list of author information \\ is available at the end of the \\ article
}

\begin{abstract}
Climate change is impacting water users in many sectors: water supply, farming, industry, hydropower, fishing, housing, navigation and health. Existing situations, like population growth, movement of populations from rural to urban areas, poverty and pollution can aggravate the impacts of climate change. The aim of the study is to evaluate the vulnerability of different water user groups to climate change and define communities' adaptation strategies in the Comoe River Basin. Information was collected on communities' concerns and perception on changes in climate and potential adaptation measures and strategies. Results show that $95 \%$ of the sample in the study communities had heard of it and are aware that climate change is occurring. They have been experiencing changes in economic activity and cropping pattern, reduced water level in rivers, crop failure, delay in cropping season, new pests and diseases, food insecurity, drop in income and decline in crop yield. Results also show that communities employ various adaptation strategies including crops diversification, substitution and calendar redefinition, agroforestry, borrowing from friends and money lenders and increasing fertilizer application.
\end{abstract}

Keywords: Climate change, Vulnerability, Water user, Adaptation strategy, Comoe River Basin

\section{Background}

CCPAN (2007) and Hope (2011) have defined climate change as any long-term significant regional change in measures of climate (such as temperature, precipitation, or wind patterns). Also, they argued that it is therefore any major long-term variation in the average weather that a given region experiences. They have stated that these variations must be statistically significant in measurements of either the mean state or variability of the climate for that region, whether due to natural factors or as a result of human activity. For them, climate change can, consequently, be regarded as a change of climate, which is attributed directly or indirectly to human activity, and which alters the composition of the global or regional atmosphere, in addition to natural climate variability over comparable time periods.

According to Fussel (2005) and weADAPT (2011), "vulnerability is a central concept in a variety of research contexts such as natural hazards and disaster management, ecology, public health, poverty and development, secure livelihoods and famine, sustainability science, land change, and climate impacts and adaptation". Parry et al. (2007) have 
defined vulnerability as "the degree to which a system is susceptible to, or unable to cope with, adverse effects of climate change, including climate variability and extremes". Vulnerability depends on exposure, sensitivity and adaptive capacity. Water users are vulnerable to changes in water resources depending on the level of socioeconomic and environmental factors. The most vulnerable communities have to be identified for the mitigating actions prioritisation within every river basin (United Nations 2009).

Populations in developing countries are more exposed to climate change and they have low capacity to react to the related impacts. There is an urge need to assess vulnerability and to plan adaptation measures. Generally, instead of being proactive communities are not prepared to react to the effects of climate change in West Africa (C3D+2013). Recurrent changing climate in West Africa has led to decrease in rainfall since the late 70s (Carbonnel and Hubert 1992; Mahé and Olivry 1995; Nicholson et al. 2000; Mahé et al. 2001; Savane et al. 2001; Tapsoba et al. 2002; Kouakou et al. 2007). This resulted in a reduction of stream flow and wetlands leading to severe droughts (Servat et al. 1998; Madiodio et al. 2004; Kouakou 2011).

Sub-Saharan Africa is mostly vulnerable to the effects of climate change (Boko et al. 2007). Predictions are showing the same impacts. Côte d'Ivoire is also experiencing the negative impacts of climate change (Bigot et al. 2005; Brou 1997; Brou 2005). This has led to decrease in rainfall from 10 to $30 \%$ across the country (Goula et al. 2006, 2009).

People's perceptions of climate change and the way they respond depend on their knowledge change (Adger et al. 2003; IFAD 2008; Nyanga et al. 2011). Communities know how climate is changing (Heijmans 2001) and their contribution is useful in identifying adaptation strategies.

The aim of the study is to evaluate the vulnerability of different water user groups to climate change and define communities' adaptation strategies in the Comoe River Basin (CRB). Findings from this study will inform policy development on adaptation measures in the CRB and more widely in West Africa.

\section{Methods}

\section{Study sites}

\section{Location and socioeconomic characteristics}

Previous studies by Kouakou et al. (2007) as well as Goula et al. (2009) identified the Comoe River Basin (CRB) as one of the most vulnerable basins in West Africa concerning changing rainfall. Also, a diagnostic analysis of the CRB revealed that one of the major problems is changes in the quantity of water and the flows seasonality which has great influence on sustainable development of water supply for industrial and agricultural productions (Goula 2012). The main socioeconomic activities are agriculture, livestock, fisheries, industry, energy, mining, river transport, tourism and crafts.

The CRB is located in West Africa between longitudes $3^{\circ}$ and $5^{\circ} 30$ West and latitudes $5^{\circ}$ and $11^{\circ} 30$ North. Comoe is the longest river of Côte d'Ivoire $(1160 \mathrm{~km})$. It extends over four countries: two landlocked countries (Burkina Faso and Mali) characterized by a Sudano-Sahelian climate and two coastal countries (Ghana and Côte d'Ivoire) with a tropical and sub-equatorial climate and covers about 78,000 $\mathrm{km}^{2}$.

This research was conducted in the southern part of the basin in Côte d'Ivoire. Four (4) regions (Indenie-Djuablin, Me, Gontougo and Iffou) and twenty-one (21) villages along 


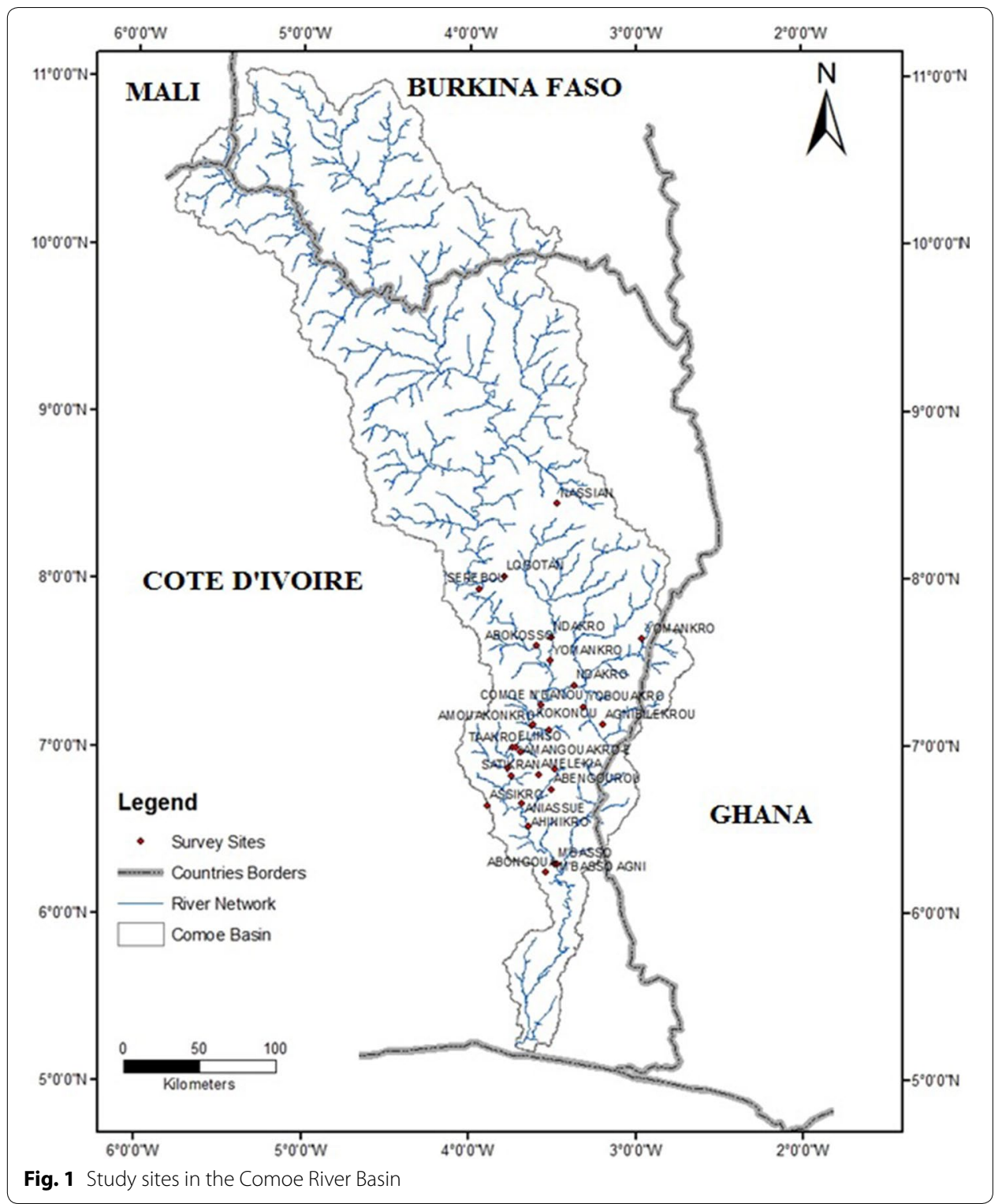

the Comoe River were visited (Fig. 1). Population of the survey areas are multi-ethnic. On the one hand, Attié, Agni, Koulango, Abron, Baoulé and Andoh make up the natives. On the other hand, non-natives are composed of people from Economic Community Of West African States (ECOWAS). Table 1 shows how some key characteristics of the survey area.

According to Salvador et al. (2004), agriculture is still the most important leverage of economic growth in West Africa where the sector plays a significant part in food security. Table 2 shows the percentage of different types of farming in the CRB.

\section{Research methods}

We assess the droughts in the CRB using the called "Standardized Precipitation Index (SPI) method" elaborated by McKee et al. (1993). Calculation was done with the following formula: 
Table 1 Key demographic and socioeconomic characteristics of the survey area

\begin{tabular}{ll}
\hline Characteristics & Study area \\
\hline Mean annual rainfall $(\mathrm{mm})$ & 1100 \\
Rainfall patterns & Bimodal \\
Mean annual temperature $\left({ }^{\circ} \mathrm{C}\right)$ & 28 \\
Main livelihood & Agriculture \\
Major crops grown & Coffee, Cocoa, Hevea, Cashew, Plantain, Yam, Pepper, \\
& Tomato, Gumbo and Aubergine \\
Types of association $(\%)$ & $11 \%$ of men, $31 \%$ of women, $28 \%$ of young, $28 \%$ \\
& of mutual, $2 \%$ of no association \\
Population in agriculture $(\%)$ & 83 \\
Ethnic composition & Attié, Agni, Koulango, Abron, Baoule and Andoh \\
\hline
\end{tabular}

Table 2 Type of crops in the study site

\begin{tabular}{llrrrr}
\hline Crop type & Crops & Indenie & Me & Gontougo & Iffou \\
\hline Cash crops & Coffee and cocoa (\%) & 34 & 50 & 25 & 25 \\
& Cashew nut (\%) & 34 & 0 & 42 & 50 \\
& Hevea (\%) & 32 & 50 & 33 & 25 \\
& Total (\%) & 100 & 100 & 100 & 100 \\
& Plantain (\%) & 20 & 25 & 13 & 11 \\
& Yams (\%) & 20 & 0 & 22 & 22 \\
& Gumbo \& Aubergine (\%) & 20 & 25 & 22 & 22 \\
& Peppers (\%) & 20 & 25 & 22 & 22 \\
& Tomatoes (\%) & 20 & 25 & 22 & 100 \\
\hline
\end{tabular}

$$
S P I_{i}=\left(\frac{X_{i}-\bar{X}}{\sigma}\right)
$$

where $\bar{X}$ indicates the mean and $\sigma$ is the standard deviation of the data series; Negative results from this formula reveal drought events, while positive results show wet events.

The sample size for the survey population was determined using the Cochran (1977) equation.

$$
n=\frac{Z^{2} P(1-P)}{C^{2}}
$$

with $\mathrm{n}=$ sample size; $\mathrm{Z}=$ confidence level; $\mathrm{P}=$ percentage in decimal; $\mathrm{c}=$ confidence interval in decimal.

The collection of data used in this study was done during one period of fieldwork; April-May 2014. The survey was conducted with a team of socioeconomics through key informant interviews, questionnaire surveys and Focus Group Discussions (FGDs). This research only considered interviews with water users and stakeholders involved in water use and management.

Information on the perception and the concerns for changing climate and potential adaptation measures and strategies, were collected through two structured 
questionnaires. The questionnaires were designed in French and the interviews were conducted in French and sometimes in the local languages, Agni, Baoule, Andoh. The following headings composed the different sections of the questionnaire:

a. Site and respondent: the first section was used to obtain information on the survey site and the water users group.

b. Social and cultural information: the second part gives information on the survey site communities, their representativeness, and social organization, everyday diseases of children, men and women.

c. Climate context: this part informs on communities' awareness of changing climate, relative risks, observed effects and local adaptation measures, vulnerable population and economic sectors to changes in climate.

d. Livelihood: we used this section to obtain information on communities' source of income, source of domestic energy, available resources to fight against natural disasters, infrastructures for water management.

e. Extreme events: the last section was used to collect information on extreme events frequency, the understanding of these extreme events, the loss of production and reduction of income.

Data from the questionnaires were analysed using Sphinx software. Meteorological data were obtained from the Burkina Faso and Cote d'Ivoire Meteorological Agencies for the period between 1941 and 2010. Rainfall and temperature data showed the trends of these climate variables and how the CRB is vulnerable to climate variability and change.

\section{Results}

Findings are presented in this part by showing the perceptions of changes in climate within the study communities and examining the various adaptation measures used to manage climate change.

\section{Climate}

Crop management needs good knowledge on the timing of the onset and cessation of the rainy season. Also, it is very important to know the period of the year with high rainfall variability (weADAPT 2013). Farming and many sectors are very sensible to rainfall variability. The survey sites lie within the equatorial climate zone (Touchebeuf and Girard 1962; Girard and Sircoulon 1968; Girard et al. 1971). Figure 2 presents historical climate monthly averages for the closest synoptic stations (Dimbokro and Bondoukou) and shows a bimodal rainfall pattern with two rainy seasons for the 1941-2010 period: one is long (from March to July) and another is short (from September to October). June is the wettest month for Dimbokro and September for Bondoukou, with a monthly average around $180 \mathrm{~mm}$ from 1941 to 2010. January is the driest month with an average of 13.6 and $9.3 \mathrm{~mm}$ of total monthly rainfall respectively for Dimbokro and Bondoukou. The driest period is November throughout February. August corresponds to an intermediary season with low rainfall. The minimum average temperature recorded from 1941 to 2010 is 20.9 and $20^{\circ} \mathrm{C}$ in January respectively for Dimbokro and Bondoukou, whereas the maximum average temperature is in February, 35.7 and $35.1^{\circ} \mathrm{C}$. 

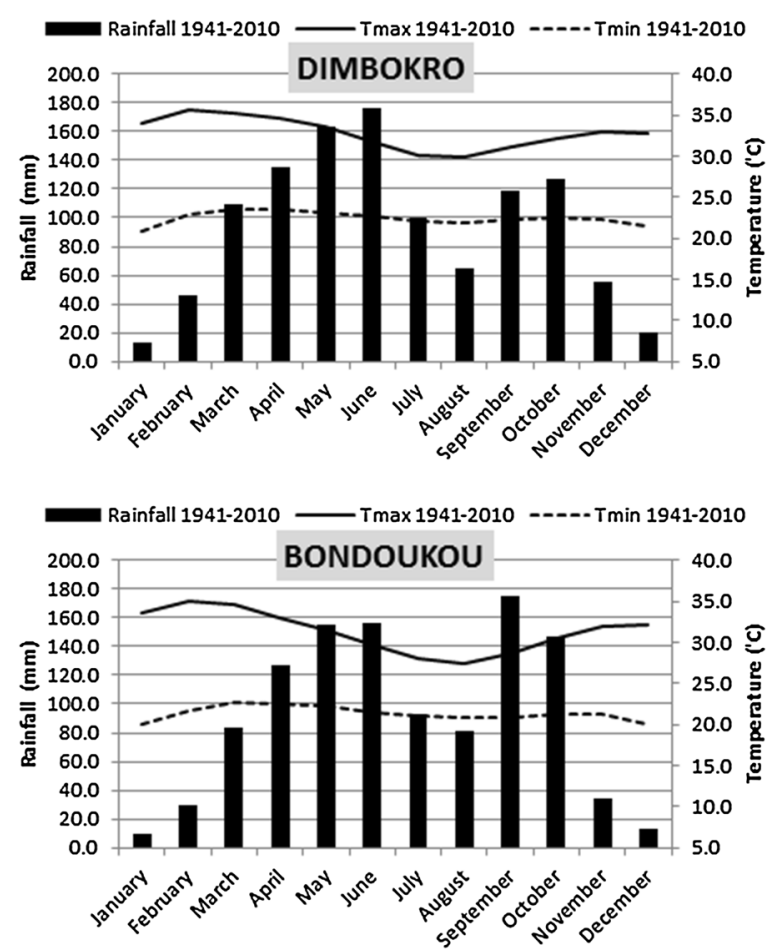

Fig. 2 Historical climate monthly averages, Dimbokro and Bondoukou stations, 1941-2010

A 55-years record of data from 6 rain gauges of the survey area examined for temporal distribution show a succession of humid and drought periods with an extreme dry period beginning in 1969 (Fig. 3). Table 3 shows a delay and a shortage of rainy seasons at Abidjan, Adiake and Dimbokro stations.

The interannual variability of temperature for the period 1941-2010 at Bondoukou and Dimbokro synoptic stations shows a continuous increase of temperature (Fig. 4). This increase is more pronounced at the minima with about $2{ }^{\circ} \mathrm{C}$ than maxima level with about $1{ }^{\circ} \mathrm{C}$. The average minima temperatures are 21.4 and $22.4{ }^{\circ} \mathrm{C}$ while the average maxima temperatures are 31.4 and $32.8{ }^{\circ} \mathrm{C}$ respectively at Bondoukou and Dimbokro. Around 1975, the observed interannual values exceeded the 1941-2010 interannual mean.

Temperature projections over West Africa using CMIP5 GCMs for RCP4.5 and RCP8.5 (Meehl et al. 2007; Fontaine et al. 2011; Diallo et al. 2012; Monerie et al. 2012) and regional downscaling (Patricola and Cook 2010, 2011; Mariotti et al. 2011; Vizy et al. 2013) are indicating an increase from 3 to $6^{\circ} \mathrm{C}$ by the end of this century. Because of convective rainfall in this region, precipitation projections are showing inter-model variation in both the amplitude and direction of change (Niang et al. 2014; Biasutti et al. 2008; Druyan 2011; Fontaine et al. 2011; Roehrig et al. 2013). For the Comoe River Basin, climate projections for this century (2031-2040 and 2094-2100), Regional Climate Model version 3 is indicating a decrease in average total monthly rainfall by 10 and $20 \%$ for the whole basin and a clear increase in monthly average temperature, about $0.62-0.74{ }^{\circ} \mathrm{C}$ for the period $2031-2040$ and $3-4.1^{\circ} \mathrm{C}$ for the period 2094-2100 (Kouakou 2011). 


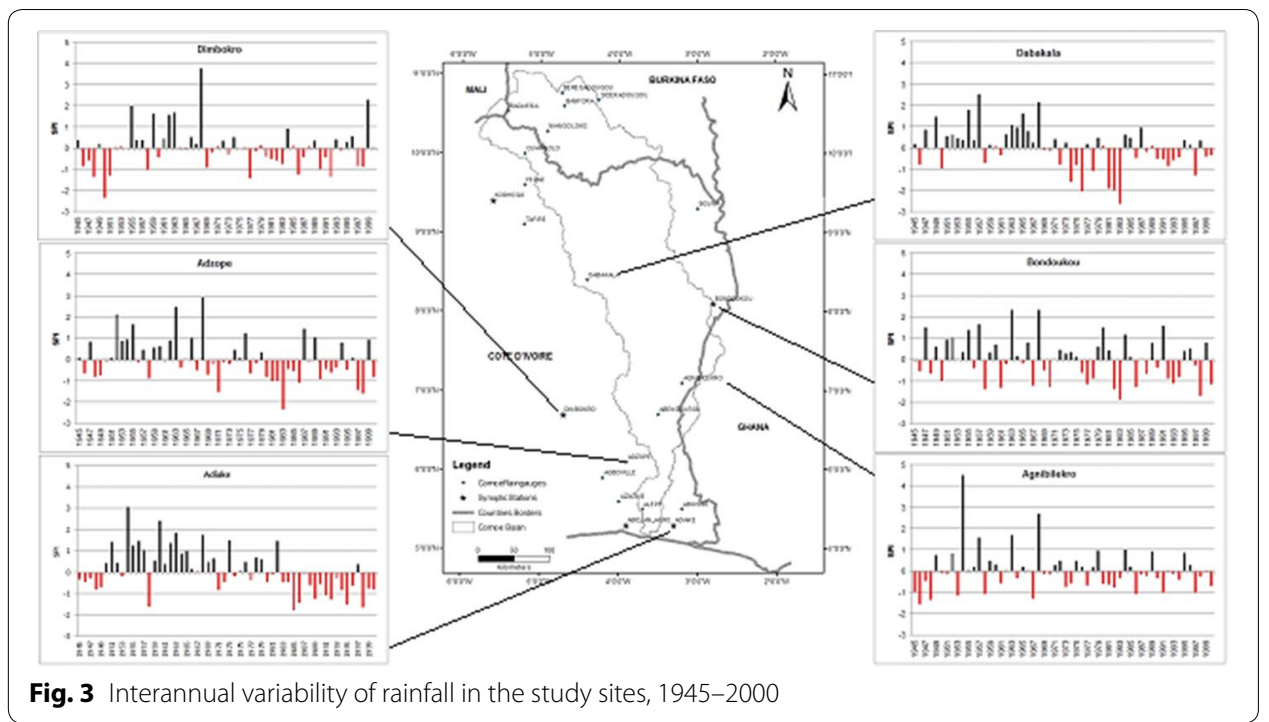

Table 3 Delay in rainy seasons

\begin{tabular}{|c|c|c|c|c|c|c|c|}
\hline \multirow[t]{2}{*}{ Station } & \multirow[t]{2}{*}{ Period } & \multicolumn{3}{|c|}{ First rainy season } & \multicolumn{3}{|c|}{ Second rainy season } \\
\hline & & Start & End & Length (days) & Start & End & Length (days) \\
\hline \multirow[t]{3}{*}{ Abidjan } & $1951-1980$ & Mar-27 & Aug-22 & 149 & Oct-11 & Dec-31 & 82 \\
\hline & $1971-2000$ & Apr-03 & Aug-17 & 137 & Oct-17 & Dec-31 & 76 \\
\hline & Delay (days) & -7 & -5 & -12 & -6 & 0 & -6 \\
\hline \multirow[t]{3}{*}{ Adiake } & $1951-1980$ & Mar-21 & Sep-23 & 187 & Sep-28 & Dec-30 & 93 \\
\hline & $1971-2000$ & Apr-08 & Sep-14 & 160 & Sep-30 & Dec-24 & 85 \\
\hline & Delay (days) & -18 & -9 & -27 & -2 & -6 & -8 \\
\hline \multirow[t]{3}{*}{ Dimbokro } & $1951-1980$ & Apr-03 & Jul-29 & 117 & Sep-11 & Nov-03 & 53 \\
\hline & $1971-2000$ & Apr-04 & Jul-11 & 98 & Sep-06 & Nov-08 & 63 \\
\hline & Delay (days) & -1 & -18 & -19 & 5 & 5 & 10 \\
\hline
\end{tabular}

River discharge

A 55-years record of river discharge at M'Basso gauging station where the mean annual flow is $167.5 \mathrm{~m}^{3} \mathrm{~s}^{-1}$, shows a decline of discharge of about $100 \mathrm{~m}^{3} \mathrm{~s}^{-1}$ in the Comoe River (Fig. 5).

\section{Water users' awareness of climate change}

The questionnaire survey was used to know if water users have heard of climate change before or if they have never heard of this concept. $95 \%$ of the interviewee in the study communities had heard of it and are aware that climate change is occurring. They had perceived climate change in terms of various changes (Fig. 6). Among them, $86 \%$ have observed late rain. Another $82 \%$ of the opinion was that rainfall has decreased and therefore increased the frequent occurrence of droughts $(27 \%)$. Majority of the water users (95 and $86 \%$ ) interviewed believe that temperature and winds are becoming warmer and stronger respectively. Going by the opinion of $91 \%$ of water users, the crop diseases and pests have increased. Only $5 \%$ of them were observing torrential rain. 

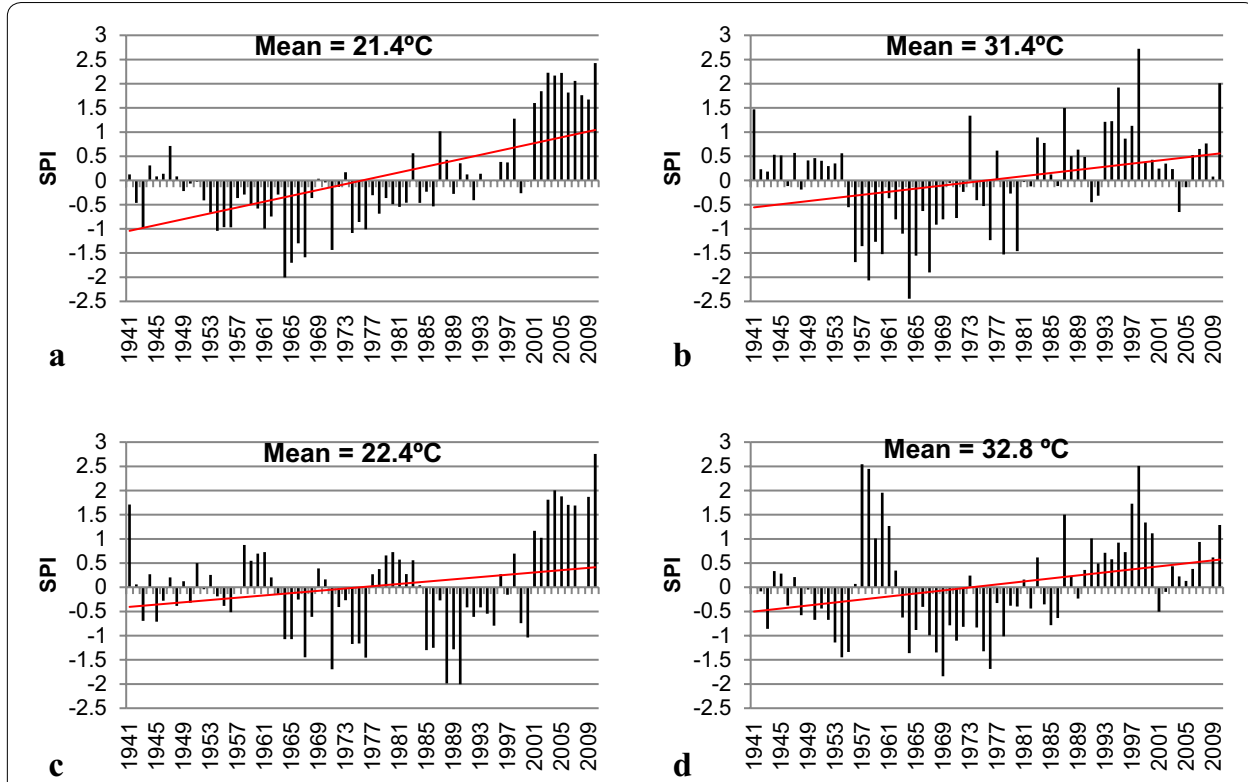

Fig. 4 Interannual variability of a minima temperature at Bondoukou, b maxima temperature at Bondoukou, c minima temperature at Dimbokro, d maxima temperature at Dimbokro, 1941-2010

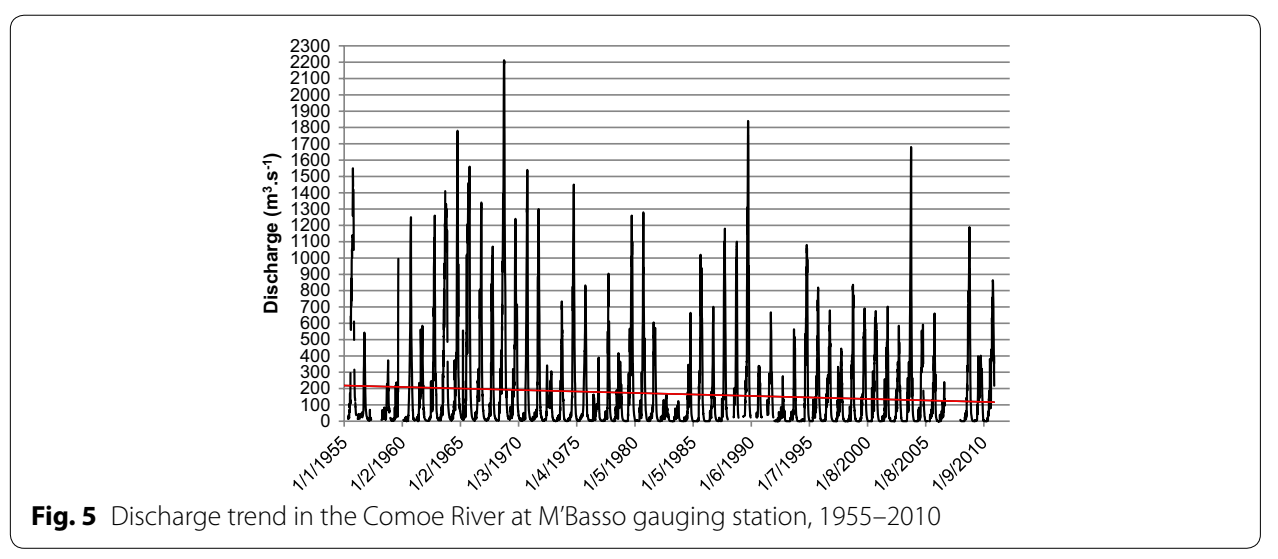

There was almost unanimous agreement across the water users that there is a delay in the onset of the rainfall compared with their childhoods.

The answer of the origin of climate change varies from literate to illiterate people. Literate interviewed water users define climate change as a change in, for example, rainfall and temperature from the past to now. For the illiterate, climate change is a divine sanction against human who have broken social values. They were of the opinion that rainfall is not coming as more as in the past because of deforestation.

\section{Socioeconomics effects of climate change}

Agriculture is the largest economic sector in the CRB and most communities reported that they have been experiencing changes in climate (Fig. 7). According to $95 \%$ of the interviewed people, crop yield is decreasing over years because of climate change, 


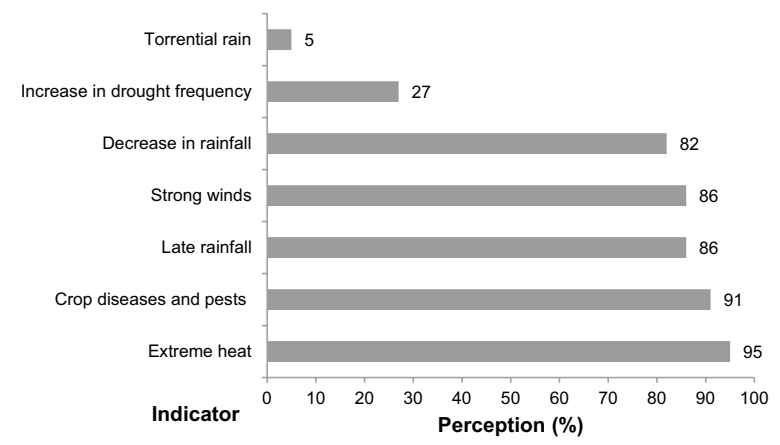

Fig. 6 Water users' perceptions about climate change in the survey area, $n=384$

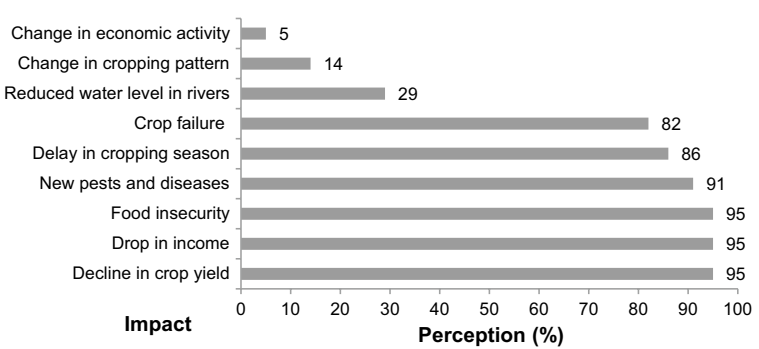

Fig. 7 Perceived impacts of climate change in the survey area, $n=384$

ultimately leading to drop in income and food insecurity. About $91 \%$ of water users noticed new pests and diseases like Swollen-Shoot in cocoa and malaria for human. While $86 \%$ of interviewed people reported a delay in cropping season, $82 \%$ noticed crop failure. One-third of them have perceived declining water level in rivers. According to $14 \%$ of the water users, there is a change in cropping pattern. About $5 \%$ of the interviewed people reported a change in economic activity. It was the case of the fishermen community of M'Basso called 'Bozos' who became farmers.

\section{Local adaptation measures}

To manage the changes perceived by communities in the CRB, various adaptation strategies have been employed. Figure 8 summarizes these and shows three broad strategies, namely, on-farm, financial and preventive adaptation strategies are undertaken by interviewed people in response to the effects of climate change.

Firstly, on-farm adaptation measures refer to agricultural management practices undertaken in the study communities and include crop diversification (64 \%), crop substitution (59\%), agroforestry (55\%) and irrigation (5\%). Secondly, financial adaptation strategies refer to income management strategies to sustain livelihood during climate adversities. These strategies include increasing fertilizer application (23\%) to improve crop productivity and borrowing from friends and money lenders (15\%). Thirdly, preventive adaptation strategies that were reported include bushfires regulation (27\%) and crop calendar redefinition (14\%). 

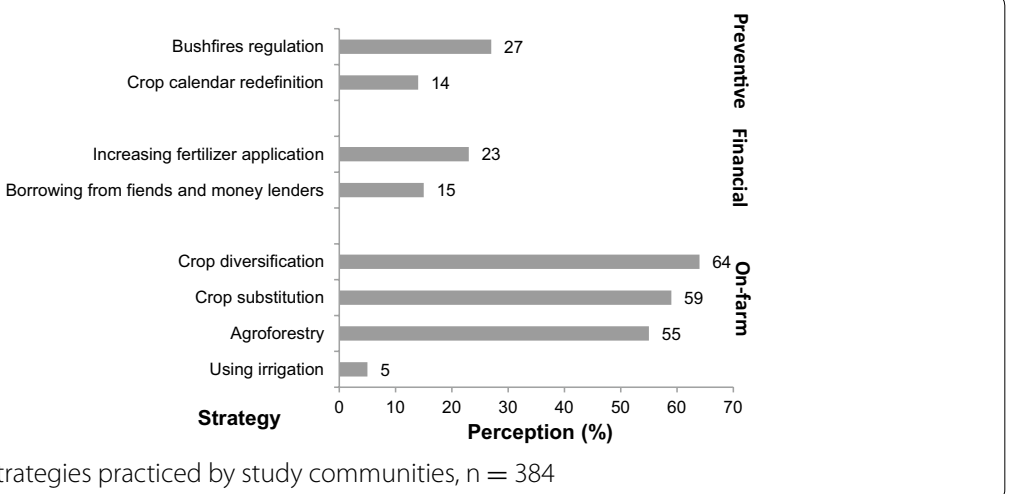

Fig. 8 Adaptation strategies practiced by study communities, $n=384$

\section{Discussion}

According to many authors, land-cover changes in tropical and subtropical Africa have led to accentuate drought occurring (Zeng and Neelin 2000; Pielke 2001; Semazzi and Song 2001; Zeng et al. 2002; Madiodio et al. 2004; Paeth et al. 2009). Both the decline of rainfall and the clear temperature rising by the middle and end of the century were found to conform to others climate projections (IPCC 2012; ECOWAS-SWAC 2008).

Water users in the CRB have heard of climate change and their understanding of it is closed to scientist definition: climate change is a change in, for example, rainfall and temperature from the past to now. Most water users have noticed that temperatures are getting warmer and there is a decline in rainfall over the last three decades. These perceptions were found to conform to the perceptions of water users in Cote d'Ivoire the last forty years (Bigot et al. 2005; Brou 2005) and in many African countries (Madison 2007; Nhemachena and Hassan 2007; Gbetibouo 2009; Ishaya and Abaje 2008; Dinar et al. 2008; Lema and Majula 2009; Mertz et al. 2009; Ayanwuyi et al. 2010; Mensah et al. 2010; Mubaya et al. 2010; Akponikpe et al. 2010; Acquah 2011; Kemausuor et al. 2011; Bryan et al. 2011; Deressa et al. 2011). Findings from Nicholson (2001) and Hope (2011) have showed that temperatures vary from day to night and throughout the year in tropical areas. Water users were also of the opinion that deforestation for cropping contribute to changes in climate.

One of the key perceived effects of changes in climate was declining in crop yield. Most of cash crops need good rainfall and their development is done to the detriment of forest areas. According to Brou (2005), Ohouo and Obodi (2011) the rate of deforestation is one of the most important rates in the world (90\%). It is the case of cocoa which need annual rainfall between 1200 and $1500 \mathrm{~mm}$ (Brou et al. 2003). Any change in such condition lead to declining in crop yield (Surre and Coomans 1972; Yao et al. 1995; Yao and Kamagate 2010). One net impact of climate change reported by respondents was pest and diseases. The recommendations for the described Cocoa swollen-shoot virus are to cut down alternative hosts. This results in a decrease of cocoa yield (Dzahini-Obiatey et al. 2010; Domfeh et al. 2011). The presence of mosquitoes is mainly a question of temperatures and humidity. Increased temperatures will increase occurrence of malaria. Crops destruction is increasing the cost of food because it is leading to low yields, food shortage and communities incomes declining (MICCA 2012). Food insecurity due 
to climate change is reality in the CRB as well as in various geographic areas of Cote d'Ivoire (Yabile 2013).

Various adaptation measures are employed by water users to respond to climate change. The foremost adaptation strategy adopted by the study communities is crop diversification. The advantage of crop diversification is in the compensation of one crop failure by the yield of another crop. Many crops are grown at the same time on the same field. Association used for cash food are cocoa + plantain; Cocoa + cashew nut; Cocoa + cashew nut + teak. For food crops concern mainly yams, groundnut, taro, tomatoes, pepper and aubergine. The second important strategy is crop substitution. Water users are now using drought-tolerant crops to secure their occupation and income from the adversities caused by climate change. Thus, they have been replacing cocoa and coffee by hevea, cashew nut and teak. Also, long duration crops and varieties are getting replaced by short duration ones. For example, the variety of cocoa called 'French cocoa' has been replaced by 'Mercedes cocoa' promoted by 'Centre National de Recherche Agronomique (CNRA).' This adaptation strategy has a negative consequence the region is nomore called 'boucle du cacao' and people are immigrating to the South East of the country. Another adaptation strategy used by the study communities is agroforestry. It concerns the use of fast-growing-species of trees in the farm. The frequent tree species are teak (Verbenaceae), framire (Terminalia ivorensis) and frake (Terminalia superba). A respondent states for example 'when there is forest, there is rain and wind speed is reduced'. Bushfires and crop calendars redefinition are preventive adaptation strategies used by water users. Respondents reported that bushfires are now well regulated with the actions of local comities and non-governmental organizations (NGO) like « SIN NAN SOPKA MIN » (e.g. fire made me poor). Also, crop calendars are redefined to facilitate adaptation by way of planning when to plant their crops. Time of rainfall has changed over the years, what the respondents termed as 'untimely rainfall' that poses much difficulty in the cultivation of crops. They usually manipulate the sowing date in accordance with the arrival of rain. Some water users rely on past rainfall patterns including the start and ending of the rainy season to form expectations and predict the rainfall patterns for the coming season. This redefinition of seasonal calendars is done most of the time in collaboration with some national agencies like ANADER (Agence National d'Appui au Développement Rural), FIRCA (Fonds Interprofessionnel pour la Recherche et le Conseil Agricoles) and SAPH (Société Africaine de Plantations d'Hévéa). Increasing fertilizer application and borrowing from friends and money lenders are financial adaptation strategies used by water users in the CRB. They resorted to these strategies to keep the household food secure and sometimes after they have run out of provisions from their own production. Getting money enables farmers to look for fertilizer and seeds of improved varieties.

\section{Conclusions}

This study presented water users' perception on changing climate in the study site based on interviews and questionnaires. Findings have revealed that $95 \%$ of the sample in the study communities had heard of climate change and are aware that it is happening. This study also, found that agriculture is the largest economic sector in the CRB. Communities have experienced changing climate as changes in economic activity and cropping 
pattern, reduced water level in rivers, crop failure, delay in cropping season, new pests and diseases, food insecurity, drop in income and decline in crop yield. Others results revealed that communities have employed various adaptation strategies such as crops diversification, substitution and calendar redefinition, agroforestry, borrowing from friends and money lenders, increasing fertilizer application, bushfires regulation and irrigation.

\begin{abstract}
Abbreviations
ANADER: Agence National d'Appui au Développement Rural; BMBF: German Federal Ministry of Education and Research; C3D+: Climate Change Capacity Development; CCPAN: Climate Change Philanthropy Action Network; CMIP5: Coupled Model Intercomparison Project Phase 5; CNRA: Centre National de Recherche Agronomique; CRB: Comoe River Basin; ECOWAS-SWAC: Economic Community of West African States-Sahel and West Africa Club; FIRCA: Fonds Interprofessionnel pour la Recherche et le Conseil Agricoles; FGDs: Focus Group Discussions; GCMs: Global Climate Models; GRP: graduate research program; IFAD: International Fund for Agricultural Development; IPCC: intergovernmental panel on climate change; MICCA: mitigation of climate change in agriculture; NGO: non-governmental organizations; RCP4.5 and RCP8.5: representative concentration pathways 4.5 and 8.5; SAPH: Société Africaine de Plantations d'Hévéa; SPI: Standardized Precipitation Index; WASCAL: West African science service center on climate change and adapted land use.
\end{abstract}

\title{
Authors' contributions
}

WEY designed and conducted the survey, analysed the data and wrote the manuscript. BTAG, BD and AA revised the draft paper and they have approved the current version for submission and publication. All authors read and approved the final manuscript.

\section{Author details}

${ }^{1}$ GRP CC \& Water Resources, University Abomey Calavi, Cotonou, Benin. ${ }^{2}$ Faculty of Science and Environment Management, University Nangui Abrogoua, Abidjan, Cote d'Ivoire. ${ }^{3}$ Department of Geography, University of Bonn, Bonn, Germany.

\section{Acknowledgements}

Authors are grateful to the Meteorological and Hydrological Agencies of Burkina Faso and Cote d'Ivoire for providing data. We thank the Reviewers and the Editor for their constructive comments. The German Federal Ministry of Education and Research (BMBF) has funded this research through the West African Science Service Center on Climate Change and Adapted Land Use (WASCAL). The study was undertaken at the University of Abomey Calavi in Benin.

\section{Competing interests}

All authors declare that they have no competing interests.

Received: 8 October 2015 Accepted: 2 June 2016

Published online: 23 June 2016

\section{References}

Acquah HD (2011) Farmers perception and adaptation to climate change: a willingness to pay analysis. J Sus Dev Africa 13(5):150-161

Adger WN, Hug S, Brown K, Conway D, Hulme M (2003) Adaptation to climate change in the developing world. Prog Dev Stud 3(3):179-195

Akponikpe PBI, Johnston P, Agbossou EK (2010) Farmers' perception of climate change and adaptation strategies in SubSaharan West Africa, 2nd international conference: climate, sustainability and development in semi-arid regions, ICID + 18, August 16-20, Fortaleza-Cear'a

Ayanwuyi E, Kuponiyi E, Ogunlade FA, Oyetoro JO (2010) Farmers perception of impact of climate changes on food crop production in Ogbomosho agricultural zone of Oyo State, Nigeria. Global J Hum Soc Sci 10(7):33-39

Biasutti M, Held IM, Sobel AH, Giannini A (2008) SST forcings and Sahel rainfall variability in simulations of the twentieth and twenty-first centuries. J Clim 21(14):3471-3486

Bigot S, Brou YT, Oszwaid J, Diedhiou A (2005) Facteurs de la variabilité pluviométrique en Côte d'Ivoire et relations avec certaines modifications environnementales. Sécheresse 16(1):5-13

Boko M, Niang I, Nyong A, Vogel C, Githeko A, Medany M, Osman-Elasha B, Tabo R, Yanda P (2007) Africa. In: Parry OF, Palutikof JP, Van Der Linden PJ, Hanson CE (eds) Climate change: impacts, adaptation and vulnerability. Contribution of working group II to the IPCC fourth assessment report. Cambridge University Press, Cambridge, pp 433-467

Brou YT (1997) Analyse et dynamique de la pluviométrie dans le Sud forestier ivoirien: recherche de corrélations entre les variables climatiques et les variables liées aux activités anthropiques. Thèse de Doctorat de 3ème cycle de I'Université de Cocody

Brou YT (2005) Climat, mutations socio-économiques et paysages en Côte d'Ivoire. Mémoire de synthèse des activités scientifiques présenté en vue de l'obtention de l'Habilitation à Diriger des Recherches. Université des Sciences et Techniques de Lille, France, p 212 
Brou YT, N'Goran JAK, Bicot S, Servat E (2003) Risque climatique et production agricole en Côte d'Ivoire: Effet des variations pluviométriques sur la production cacaoyère: In: Actes de la $14^{\text {ème }}$ Conférence Internationale sur la Recherche Cacaoyère. Accra. pp 259-267

Bryan E, Ringler C, Okoba B, Roncoli C, Silvestri S (2011) Adapting agriculture to climate change in Kenya: household and community strategies and determinants, ILRI Report to the World Bank for the Project "Adaptation of Smallholder Agriculture to Climate Change in Kenya"

Carbonnel JP, Hubert P (1992) Pluviométrie en Afrique de l'Ouest soudano-sahélienne. Remise en cause de la stationnarité des séries. In: L'aridité, une contrainte au développement, ORSTOM, pp 37-51

Climate Change Capacity Development (C3D+) project (2013) Guidebook for researchers and adaptation practitioners working with local communities. adaptation toolkit. Anna Taylor, Stockholm Environment Institute (SEI), Oxford

Climate Change Philanthropy Action Network (CCPAN) (2007) Climate change glossary. http://www.climatephilanthropists.org/basics. Accessed 20 May 2009

Cochran WG (1977) Sampling techniques, 3rd edn. Wiley, New York

Deressa TT, Hassan RM, Ringler C, Alemu T, Yesuf M (2011) Perception of and adaptation to climate change by farmers in the Nile Basin of Ethiopia. J Agric Sci 149:23-31

Diallo I, Sylla MB, Giorgi F, Gaye AT, Camara M (2012) Multimodel GCM/RCM ensemble-based projections of temperature and precipitation over West Africa for the early 21st century. Int J Geophys 2012:972896. doi:10.1155/2012/972896

Dinar A, Hassan R, Mendelsohn R, Benhin J (2008) Climate change and agriculture in Africa: impact assessment and adaptation strategies. Earthscan, London, pp 100-106

Domfeh O, Dzahini-Obiatey H, Ameyaw GA, Abaka-Ewusie K, Opoku G (2011) Cocoa swollen shoot virus disease situation in Ghana: a review of current trends. Afr J Agric Res 6(22):5033-5039

Druyan LM (2011) Studies of 21st-century precipitation trends over West Africa. Int J Climatol 31(10):1415-1424

Dzahini-Obiatey H, Domfeh O, Amoah FM (2010) Over seventy years of a viral disease of cocoa in Ghana: from researchers' perspective. Afr J Agric Res 5:476-485

ECOWAS-SWAC (2008) Climat et changements climatiques en Afrique de l'Ouest. Atlas de I'Intégration Régionale en Afrique de l'Ouest, CSAO/OCDE, ILSS, FAO

Fontaine B, Roucou P, Monerie P-A (2011) Changes in the African monsoon region at medium-term time horizon using 12 AR4 coupled models under the A1B emissions scenario. Atmos Sci Lett 12(1):83-88

Fussel HM (2005) Vulnerability in climate change research: a comprehensive conceptual framework. formal approaches to vulnerability assessment that informs adaptation (FAVAIA) working paper 2, Potsdam Institute for Climate Impact Research and Stockholm Environment Institute

Gbetibouo GA (2009) Understanding farmers' perceptions and adaptations to climate change and variability: the case of the Limpopo Basin, South Africa. International Food Policy Research Institute (IFPRI) Discussion Paper, Washington, $\mathrm{DC}, \mathrm{pp} 1-2$

Girard G, Sircoulon J (1968) Etude de reboisement et de protection des sols. République de Côte d'Ivoire. Partie hydrologique, ORSTOM, Adiopodoumé

Girard G, Sircoulon J, Touchebeuf DL (1971) Aperçu sur les régimes hydrologiques. Le milieu naturel de la Côte d'Ivoire. Mém. ORSTOM, 50, Paris, pp 109-155

Goula BTA (2012) Etudes relatives à la promotion de trois (3) nouvelles organisations de bassins transfrontaliers en Afrique de l'Ouest: Comoé-Bia-Tanoé/CCRE/CEDEAO

Goula BTA, Savane I, Konan B, Fadika V, Kouadio GB (2006) Impact de la variabilité climatique sur les ressources hydriques des bassins de N'Zo et N'Zi en Côte d'Ivoire (Afrique tropicale humide). Vertigo 7(1):1-12

Goula BTA, Kouassi WF, Fatika V, Kouakou KE, Savané I (2009) Impacts du changement climatique et de la variabilité climatique sur les eaux souterraines en zone tropicale humide: cas du bassin versant de la Comoé. Int Assoc Hydrol Sci 334:190-202

Heijmans A (2001) Vulnerability: a matter of perception. Disaster management Working Paper 4. University College of London

Hope Sr KR (2011) Climate change in the context of urban development in Africa. In: Climate change and sustainable urban development in Africa and Asia. Springer, Berlin, pp 37-55

IFAD (International Fund for Agricultural Development) (2008) Climate change and the future of smallholder agriculture: How can rural poor people be part of the solution to climate change? Discussion Paper, Round Table on Climate Change at the Thirty-first Session of IFAD's Governing Council, Rome

IPCC (2012) Managing the risks of extreme events and disasters to advance climate change adaptation. A special report of working groups I and II of the intergovernmental panel on climate change In: Field CB, Barros V, Stocker TF, Qin D, Dokken DJ, Ebi KL, Mastrandrea MD, Mach KJ, Plattner G-K, Allen SK, Tignor M, Midgley PM, editors. Cambridge University Press, Cambridge

Ishaya S, Abaje IB (2008) Indigenous People's perception on climate change and adaptation strategies in Jema'a local Government Area of Kaduna State, Nigeria. J Geogr Reg Planning 1(8):138-143

Kemausuor F, Dwamena E, Plange AB, Baffour NK (2011) Farmers' perception of climate change in the Ejura-Sekyedumase District of Ghana. ARPN J Agric Biol Sci 6(10):26-37

Kouakou KE (2011) Impacts de la variabilité climatique et du changement climatique sur les ressources en eau en Afrique de I'Ouest: Cas du bassin versant de la Comoé. Thèse de l'Université d'Abobo-Adjamé

Kouakou KE, Goula BTA, Savane I (2007) Impacts de la variabilité climatique sur les ressources en eau de surface en zone tropicale humide: cas du bassin versant transfrontalier de la Comoé (Côte d'Ivoire—Burkina-Faso). Eur J Sci Res 16(1):31-43

Lema MA, Majula AE (2009) Impacts of climate change, variability and adaptation strategies on agriculture in semi-arid areas of Tanzania: the case of Manyoni District in Singida Region, Tanzania. Afr J Environ Sci Technol 3(8):206-218

Madiodio N, Abe A, Abou A (2004) Réduire la vulnérabilité de l'Afrique de l'Ouest aux impacts du climat sur les ressources en eau, les zones humides et la désertification. UICN_Union mondiale pour la nature

Madison D (2007) The perception of and adaptation to climate change in Africa, Policy Research Working Paper 4303, World Bank 
Mahé G, Olivry JC (1995) Variations des précipitations et des écoulements en Afrique de l'ouest et centrale de 1951 à 1989. Sécheresse 6(1):109-117

Mahé G, L'Hôte Y, Olivry JC, Wotling G (2001) Trends and discontinuities in regional rainfall of West and Central Africa (1951-1989). Hydrol Sci J 46(2):211-226

Mariotti L, Coppola E, Sylla MB, Giorgi F, Piani C (2011) Regional climate model simulation of projected 21st century climate change over an all-Africa domain: comparison analysis of nested and driving model results. J Geophys Res D Atmos 116(D15):D15111. doi:10.1029/2010JD015068

McKee TB, Doesken NJ, Kleist J (1993) The relationship of drought frequency and duration to time scales. 8th conference on applied climatology, Anaheim, pp 179-184

Meehl GA, Covey C, Delworth T, Latif M, McAvaney B, Mitchell JFB, Stouffer RJ, Taylor KE (2007) The WCRP CMIP3 multimodel dataset: a new era in climatic change research. Bull Am Meteorol Soc 88(9):1383-1394

Mensah BYF, Vlek PLG, Manschadi AH (2010) Farmers' perception and adaptation to climate change: A case study of Sekyedumase District in Ghana, Poster Presented in the Conference "World food system—a contribution from Europe", Tropentag, September 14-16, Zurich

Mertz O, Halsnaes K, Olesen JE, Rasmussen K (2009) Adaptation to climate change in developing countries. Envir Manage 43:743-752

Mitigation of Climate Change in Agriculture (MICCA) Programme (2012) Socio-economic Survey EADD-MICCA Pilot Project in Kenya. Food and Agriculture Organization of the United Nations (FAO), Background Report 4

Monerie P-A, Fontaine B, Roucou P (2012) Expected future changes in the African monsoon between 2030 and 2070 using some CMIP3 and CMIP5 models under a medium-low RCP scenario. J Geophys Res D Atmos 117(16):D16111. doi:10.1029/2012JD017510

Mubaya CP, Njuki J, Liwenga E, Mutsvangwa EP, Mugabe FT (2010) Perceived impacts of climate related parameters on smallholder farmers in Zambia and Zimbabwe. J Sustain Dev Africa 12(5):170-186

Nhemachena C, Hassan R (2007) Micro-level analysis of farmers' adaptation to climate change in Southern Africa, IFPRI Discussion Paper 00714

Niang I, Ruppel OC, Abdrabo MA, Essel A, Lennard C, Padgham J, Urquhart P (2014) Africa. In: Barros VR, Field CB, Dokken DJ, Mastrandrea MD, Mach KJ, Bilir TE, Chatterjee M, Ebi KL, Estrada YO, Genova RC, Girma B, Kissel ES, Levy AN, MacCracken S, Mastrandrea PR, White LL (eds) Climate Change 2014: Impacts, Adaptation, and Vulnerability. Part B: regional aspects. Contribution of Working Group II to the Fifth Assessment Report of the Intergovernmental Panel on Climate Change. Cambridge University Press, Cambridge, pp 1199-1265

Nicholson SE (2001) Climatic environmental change in Africa during the last two centuries. Clim Res 17(2):123-144

Nicholson SE, Some B, Koné B (2000) An analysis of recent rainfall condition in West Africa, including the rainy seasons of the 1997 El Nino and the 1998 La Nina years. J Clim 13:2623-2639

Nyanga H, Johnsen FH, Aune JB, Kalinda TH (2011) Smallholder farmers' perceptions of climate change and conservation agriculture: evidence from Zambia. J Sustain Develop 4(4):73-85

Ohouo Obodi MAL (2011) Apport de l'Agroclimatolgie dans la Régénération forestière en Côte d'Ivoire. Mémoire de Fin d'Etudes. 98p

Paeth H, Born K, Girmes R, Podzun R, Jacob D (2009) Regional climate change in tropical and Northern Africa due to Greenhouse forcing and land use changes. J Clim 22:114-132

Parry ML, Canziani OF, Palutikof JP, van der Linden PJ, Hanson CE, (2007) Climate change: impacts, adaptation and vulnerability. Contribution of Working Group II to the fourth assessment report of the Intergovernmental Panel on Climate Change. Cambridge: Cambridge University Press: 1-16

Patricola CM, Cook KH (2010) Northern African climate at the end of the twenty-first century: an integrated application of regional and global climate models. Clim Dyn 35(1):193-212

Patricola CM, Cook KH (2011) Sub-Saharan Northern African climate at the end of the twenty-first century: forcing factors and climate change processes. Clim Dyn 37(5-6):1165-1188

Pielke RA (2001) Influence of the spatial distribution of vegetation and soils on the prediction of cumulus convective rainfall. Rev Geophys 39:151-177

Roehrig R, Bouniol D, Guichard F, Hourdin F, Redelsperger JC (2013) The present and future of the West African monsoon: a process-oriented assessment of CMIP5 simulations along the AMMA transect. J Clim 26(17):6471-6505

Salvador Barrios, Bazoumanna Ouattara, Eric Strobl (2004) The Impact of Climatic Change on Agricultural Production: Is it different for Africa? Institute for Prospective Technological Studies, Joint Research Centre, European Commission. Munich Personal RePEc Archive (MPRA) Paper N 6240. 22p

Savane I, Coulibaly KM, Gioan P (2001) Variabilité climatique et ressources en eaux souterraines dans la région semimontagneuse de Man. Sécheresse 12(4):231-237

Semazzi FHM, Song Y (2001) A GCM study of climate change induced by deforestation in Africa. Clim Res 17:169-182

Servat E, Paturel JE, Kouame B, Travaglio M, Ouedraogo M, Boyer JF, Lubes-niel H, Fritsch JM, Masson JM, Marieu B (1998) Identification, caractérisation et conséquences d'une variabilité hydrologique en Afrique de I'Ouest et centrale. IAHS Publ 252:323-337

Surre CH, Coomans P (1972) Les champs de comportement de palmiers à huile en Côte d'Ivoire: premiers résultats. Oléagineux 27:297-302

Tapsoba D, Bobbé B, Lebarbe L (2002) Quelques caractéristiques événementielles des régimes pluviométriques ponctuels Ouest africains au cours des deux périodes climatologiques contrastées (1951-1970 et 1971-1991). Application de la loi composée poisson/exponentielle (LCPE) ou du modèle de la loi des fuites (LDF) aux pluies. Sécheresse 13(4):95-103

Touchebeuf DL, Girard G (1962) Données sommaires sur les régimes hydrologiques de Côte D'Ivoire. EDF et ORSTOM, p 24

United Nations (2009) Guidance on Water and Adaptation to Climate Change, p 127

Vizy EK, Cook KH, Cretat J, Neupane N (2013) Projections of a wetter Sahel in the twenty-first century from global and regional models. J Clim 26(13):4664-4687 
weADAPT (2011) Vulnerability definitions. https://www.weadapt.org/knowledge-base/vulnerability/vulnerability-definitions (6 Oct 2015)

weADAPT (2013) Using climate information to support adaptation planning and policy-making: A practical case study in Bagamoyo District, coastal Tanzania. https://www.weadapt.org/knowledge-base/using-climate-information/ tanzania-using-climate-information-case-study (6 Oct 2015)

Yabile KR (2013) Déterminants de la sous-alimentation des ménages en Côte d'Ivoire: cas des régions Centre et CentreEst. Eur Sci J 9(14):207-228

Yao NR, Kamagate DK (2010) Production du palmier à huile (Elaeis guineensis JACQ.) et taux d'extraction dans des conditions climatiques marginales au Nord-est de la Côte d'Ivoire. Agron Afr 22(2):149-161

Yao NR, Orsot-Dessi DS, Ballo K, Fondio L (1995) Déclin de la pluviosité en Côte d'Ivoire et son impact éventuel sur la production du palmier à huile. Sécheresse 6:265-271

Zeng N, Neelin JD (2000) The role of vegetation-climate interaction and interannual variability in shaping the African Savanna. J Clim 13:2665-2670

Zeng N, Hales K, Neelin JD (2002) Nonlinear dynamics in a coupled vegetation atmosphere system and implications for desert-forest gradient. J Clim 15:3474-3487

\section{Submit your manuscript to a SpringerOpen ${ }^{\circ}$ journal and benefit from:}

- Convenient online submission

\section{Rigorous peer review}

- Immediate publication on acceptance

- Open access: articles freely available online

- High visibility within the field

- Retaining the copyright to your article

Submit your next manuscript at $\boldsymbol{\nabla}$ springeropen.com 